\title{
O POJĘCIU WSPÓLNOTY ZAŁOGI W PRAWIE PRACY
}

\author{
Abstract \\ The concept of the community crew in labour law
}

The article discusses the concept of the community crew in labour law and the neeed for its formation in modern workplaces. The Author presents exsisting impact of the crew on the employer's situation, and the community crew concept as a value.

Słowa kluczowe: załoga zakładu pracy, prawo pracy, zakład pracy, pracodawca

Key words: community crew, labour law, workplace, employer

\section{Wstęp}

Prawo pracy jest produktem stosunków zaistniałych między instytucjami oddziałującymi na społeczny ustrój pracy; pracowników, pracodawców i ich organizacji oraz państwa ${ }^{1}$. Niemniej wiele aspektów prawa pracy jest w dalszym ciągu nie do końca zbadane. Takim obszarem jest zagadnienie wspólnoty załogi, choć pojęcie wspólnoty załogi zakładu pracy nie jest obce doktrynie prawa pracy, w szczególności obecnie. Nie jest to jednak termin stricte prawniczy, gdyż nie został zawarty w żadnym akcie prawnym². Jest to raczej pojęcie ze sfery socjologicznej. Niemniej używanie pojęcia wspólnoty załogi ma istotne znaczenie w prawie pracy. Wynika to z faktu, że wspólnota załogi zakładu pracy ma wyraźne odniesienie do sfery aksjologicznej. Jest mianowicie wyrazem pewnych idei, wspólnych wartości, o znacznym wprawdzie charakterze ogólności, które jednak powinny być chronione. Niniejsze opracowanie, mające charakter bardzo skrótowy i wskazujące tylko niektóre problemy badawcze, jest przyczynkiem do szerszej dyskusji doktrynalnej w tym zakresie.

${ }^{1}$ A. Świątkowski, Współczesne brytyjskie zbiorowe prawo pracy, w: Prawo pracy państw obcych, M. Matey (red.), t. III, Wrocław 1989, s. 334.

${ }^{2} \mathrm{~W}$ najnowszej literaturze zagadnienie to szeroko analizuje A. Sobczyk, Wolność pracy i władza, Warszawa 2015. 


\section{Pojęcie wspólnoty zakładu pracy}

W doktrynie polskiego prawa pracy problematyka wspólnoty załogi była już poruszana w starszej literaturze przedmiotu, jednak marginalnie. Bardzo skrótowo przedstawiając powyższą problematykę według T. Zielińskiego, zachodnia doktryna posługiwała się teorią wspólnoty, realizując za jej pomocą różne cele. Pierwotnie wskazywała między innymi, że zakład pracy stanowi dobro wspólne pracowników i pracodawców. Przestaje być zatem terenem ścierania się sprzecznych interesów stron złączonych umową o pracę. W późniejszym okresie jedną z form przeciwstawiania się antagonizmów jest rozwój ważnych form uczestnictwa pracowników w zarządzaniu zakładem pracy. Przedstawione tendencje znajdują także oparcie w teorii opowiadającej się za przekształcaniem umów o pracę $\mathrm{w}$ tak zwany akcjonariat pracowniczy polegający na połączeniu udziału pracowników w zyskach z udziałem własności przedsiębiorstwa ${ }^{3}$. Elementy tego zagadnienia można znaleźć także w opracowaniach K. Kolasińskiego ${ }^{4}$ czy w wywodach zawartych w podręczniku J. Jaśkiewicza, C. Jackowiaka i W. Piotrowicza ${ }^{5}$. Ponadto w pewnym zakresie wypowiedział się o nim M. Święcicki ${ }^{6}$. Krytycznie natomiast na temat tej koncepcji wypowiedział się W. Szubert ${ }^{7}$, uznając, że wspólnotę charakteryzuje bezkonfliktowość, która nie występuje w relacjach pracownik-pracodawca. Wśród starszej literatury nie można także pominąć poglądów (oczywiście uwzględniając kontekst epoki, w jakiej poglądy te były formułowane) J. Jończyka ${ }^{8}$, który dokonuje między innymi charakterystyki prawnej w odniesieniu do pojęcia załogi (to jest kolektywu pracowników bez kierownika), czy W. Sanetry ${ }^{9}$, który stawia pytania dotyczące relacji pojęć „zakład pracy” i „załoga”. Wskazuje przy tym, że załogę należy traktować jako organ zakładu pracy. Z kolei w najnowszych poglądach doktryny prawa pracy zagadnienie wspólnotowości jest sygnalizowane przez T. Liszcz, lecz wyłącznie w celach dydaktycznych ${ }^{10}$. Istotny głos w dyskusji zajął obecnie A. Sobczyk ${ }^{11}$, zadając między innymi pytanie: Skoro pracownicy

3 T. Zieliński, Prawo pracy. Zarys systemu. Część I. Ogólna, Warszawa-Kraków 1986, s. 112 i n. Autor ten opisał między innymi zachodnie doktryny prawne (syndykalizm, etatyzm) oraz dokonał analizy doktryn socjalistycznych, przywołując przy tym ówczesną literaturę. Jak zauważył A. Sobczyk (Wolność..., s. 118), wypowiedzi T. Zielińskiego są wolne od ocen ideologicznych, a nawet ocen negatywnych. Występuje u T. Zielińskiego brak kategorycznie negatywnych ocen doktryn zachodnioeuropejskich. Z kolei rozpatrując doktrynę socjalistyczną, nie przedstawia jej jako teorii rozwiązujących słabość poglądów zachodnich, a wręcz przeciwnie, zastane teorie socjalistyczne poddane zostały krytyce.

${ }^{4}$ K. Kolasiński, Prawo pracy i ubezpieczeń społecznych, Toruń 1997, s. 131-132.

${ }^{5}$ J. Jaśkiewicz, C. Jackowiak, W. Piotrowicz, Prawo pracy w zarysie, Poznań 1980, s. 35-38.

${ }_{6}$ M. Święcicki, w: Z. Salwa, W. Szubert, M. Święcicki, Podstawowe problemy prawa pracy, Warszawa 1957, s. 69 i n.

7 W. Szubert, O charakterze prawnym stosunku pracy, Państwo i Prawo 1964, 7, s. 88-89.

8 J. Jończyk, Zakład pracy, w: Zakład pracy. Materiały IV Zimowej Szkoły Prawa Pracy, Karpacz, styczeń 1977, Wrocław 1977.

9 W. Sanetra, Załoga zakładu pracy, w: Zakład pracy. Materiały IV Zimowej Szkoły Prawa Pracy, Karpacz, styczeń 1977, Wrocław 1977.

10 T. Liszcz, Prawo pracy, Warszawa 2014, s. 94-95.

${ }^{11}$ Przywołany A. Sobczyk, Wolność..., w wielu miejscach, między innymi s. 119-121. 
mają prawo do współzarządzania zakładem pracy, to czyj jest zakład pracy i czym jest zakład pracy? Wskazuje między innymi, że wspólnotowość zakładu pracy obejmuje wspólne prowadzenie działalności gospodarczej. Nie jest to jednak wystarczające, gdyż zakład pracy łączy osoby, których życie w istotny sposób skupione jest wokół przedsiębiorstwa i w jakiejś części uzależnione od jego ekonomicznego powodzenia, a tym samym od jego istnienia. Członkami wspólnoty zakładu pracy są nie tylko pracownicy, lecz także ich rodziny, byli pracownicy i pracodawca wraz z jego rodziną. Należą do niej także osoby pozostające w niepracowniczym stosunku zatrudnienia.

\section{Potrzeba budowania wspólnoty załogi}

Współczesna cywilizacja jest cywilizacją wspólnoty ludzkiej. Obecnie człowiek nie żyje samodzielnie, w izolacji. Człowiek jest istotą społeczną, co oznacza, że funkcjonuje zawsze obok kogoś lub wraz z kimś. Jest to widoczne nie tylko w sferze relacji interpersonalnych, lecz także w sferze kulturowej czy ekonomicznej (obecnie nie ma państw samowystarczalnych, a próby dążenia do tak zwanej autarkii ze względów ekonomicznych są nieefektywne, złudne i często zbędne). Z tego też powodu człowiek potrzebuje wspólnoty i w tym celu dąży do jej zbudowania. Tą wspólnotą jest załoga zakładu pracy.

Wspólnoty ludzi nie można narzucić czy utworzyć odgórnie. Żadne bowiem regulacje prawne nie są w stanie w sferze psychicznej i socjologicznej zmusić kogokolwiek do bycia we wspólnocie. Nawet jeżeli zostaną przyjęte odgórnie rozwiązania prawne, to wspólnota taka będzie jedynie fikcją, jaką w PRL były związki zawodowe odbiegające od powszechnie obowiązującej w świecie cywilizowanym formy ochrony pracowników. Próby tworzenia wspólnoty odgórnie, na przykład przez systemy totalitarne, jakimi były komunizm czy faszyzm, szybko okazywały się „puste” i rozpadały się w wyniku zmieniających się okoliczności faktycznych. Brak powiązań społecznych doprowadza z czasem do ich realnego zaniku.

Każdą wspólnotę tworzy się od dołu. Jest to proces dynamiczny i długotrwały. Wspólnotę tworzy się autonomicznie, gdyż jest ona wyrazem wzajemnej więzi, powiązań społecznych, kulturowych, środowiskowych, ekonomicznych czy interpersonalnych. Kreuje się ona w wyniku usuwania barier nieufności, gdyż w nieufności widzi się mechanizm obronny. Najważniejszą rzeczą w budowaniu wspólnoty jest opieranie się na wzajemnym zaufaniu, a nie odruchach, wrażeniach czy powierzchownych, często irracjonalnych przesłankach. Aby obdarzyć kogoś zaufaniem, trzeba coś o nim wiedzieć, stąd niezbędne są stałe bilateralne relacje pomiędzy ludźmi. Budowanie tych relacji musi być oparte na ogólnych założeniach aksjologicznych, a więc na pewnych założeniach, wzorcach, wartościach, którymi wspólnota powinna się kierować i ich następnie przestrzegać (chronić). Pojawia się zatem kategoria dobra wspólnego, wzajemnych, wspólnych wartości dla wszystkich członków takiej wspólnoty. Stąd w procesie budowania czegoś, co można nazwać dobrem wspólnym, niezbędna jest konsekwencja i pozostawanie 
w zgodności z uznawanymi wartościami. Członkowie wspólnoty muszą udzielać sobie zatem kredytu zaufania.

Osobnego podkreślenia wymaga fakt, że oddolne tworzenie jakiejkolwiek wspólnoty napotyka szczególną barierę. Wynika to $\mathrm{z}$ tego, że człowiek z uwagi na swoją naturę ogólnie zorientowany jest na zaspokajanie własnych potrzeb lub potrzeb osób z różnych względów jemu bliskich (np. rodziny). Stąd dopiero wzajemne oddziaływanie, przestrzeganie wzajemnie uznanych wartości powoduje, że możliwe jest kształtowanie wzajemnych więzów lojalności i poczucia tym samym wspólnoty interesów, praw, sprawiedliwości czy szacunku. Tworzy się tym samym wartość, którą można nazwać kapitałem społecznym. Kapitał społeczny będzie niczym innym, jak siatką wzajemnych relacji, powiązań, a nawet zależności w danym środowisku.

Rozważania w przedmiocie pojęcia „wspólnota załogi” narażone są na niebezpieczeństwo ogólnikowości i nadmiernego schematyzmu. Jest to bowiem pojęcie nieostre, a więc nie jest to kategoria zamknięta. Wspólnota pracowników jest wybitnie heterogeniczna. Stąd pojęcie to nie jest jednoznaczne, nie ma jednego określonego desygnatu. Jest złożone i uwarunkowane także $\mathrm{z}$ uwagi na typ pracodawców (inną wspólnotę tworzą pracownicy u pracodawców wykonujący zadania produkcyjne, a inną na przykład u pracodawców funkcjonujących w zakresie kultury i oświaty). Inną wspólnotę tworzą także pracownicy z uwagi na charakter pracodawców - wielkich przedsiębiorstw (wielozakładowych), często o charakterze ponadnarodowym, średnich i małych. W ramach wspólnoty wystąpią odmienne cele, dążenia i interesy (na przykład pracownicy tak zwani administracyjni i produkcyjni, gdyż ci ostatni mogą dążyć do stałego świadczenia pracy w nadgodzinach w celu zwiększenia wynagrodzenia). Z tego też względu mówiąc o wspólnocie pracowników, musimy mieć na uwadze, że występują różne wspólnoty, w których występują różnice ich celów, powodujące w konsekwencji jej odmienności strukturalne i prawne (na przykład w zakresie powołania lub nie związków zawodowych czy rad pracowników). Stąd rozpatrując pojęcie „wspólnota załogi”, należy zwrócić uwagę na to, że problematyka ta jest wieloaspektowa, a zatem szczególnie trudna. Struktura pracodawców jest często bardzo złożona, a to implikuje „życie” wewnętrzne takiej wspólnoty. Utrudnia także „współzarządzanie” zakładem pracy. Można zatem wysnuć konstrukcję podzielonej podmiotowości wspólnoty załogi. Wpływ na wspólnotę ma zakres terytorialnego rozproszenia jednostek organizacyjnych pracodawcy, co także warunkuje skuteczność podejmowanych decyzji. Wspólnota pracowników jest zbiorem ogółu pracowników, jednakże tworem wielopodmiotowym, w którym mogą powstać odmienne, partykularne dążenia. Wystąpić może zjawisko atomizacji celów jednostkowych, co może prowadzić do ujawniania się mocno wewnętrznych konfliktów w takiej podmiotowości. Jednakże z uwagi na to, że jest to wspólnota, dążenia partykularne powinny być eliminowane w przypadku wspólnych, „strategicznych” celów. Funkcją wspólnoty jest zatem osiąganie wspólnych celów, co jest jednak uzależnione od różnych czynników zarówno wewnętrznych, jak i zewnętrznych oraz kompetencyjnych (na przykład z uwagi na to, kto reprezentuje pracowników - związki zawodowe czy rady pracowników, a więc czy mają te reprezentacje także kompetencje w zakresie stanowienia 
prawa, czy tylko i wyłącznie kompetencje opiniodawczo-konsultacyjne). Wspólnota tworzy hierarchię interesów. Słaba pozycja podmiotów przedstawicielskich wspólnoty często uniemożliwia skuteczną walkę o prawa i interesy załogi, na przykład w zakresie tworzenia funduszy zakładowych (funduszu płac, funduszu socjalnego). To wpływa na zakres funkcji dystrybucyjnej.

Przechodząc do głównego nurtu rozważań, a mianowicie potrzeby budowania wspólnoty załogi w zakładzie pracy, należy uznać, że budowanie tej wspólnoty oparte musi być na szczególnym kapitale społecznym ${ }^{12}$. Kapitał ten musi się wspierać na wzajemnym zrozumieniu potrzeb stron stosunków pracy (zarówno indywidualnych, jak i zbiorowych). Powinno być wzajemne zrozumienie potrzeb zatrudnionych pracowników ( $w$ tym także zatrudnionych na umowy cywilnoprawne), w szczególności sprowadzające się do uzyskiwanych lepszych (wyższych) zarobków, ale też zauważanie potrzeb pracodawcy, przy braku jego personifikacji, nastawionych na konieczność rozwoju, innowacyjności czy konieczności przeprowadzania inwestycji. Stąd kapitałem społecznym będzie uznanie, że z uwagi na niski zasób finansowy pracodawcy nie jest możliwe dokonanie wzrostu wynagrodzeń. Z kolei w sytuacji dobrej koniunktury i braku wyraźnej potrzeby inwestycyjnej możliwość przeznaczenia „bez oporu” przez pracodawcę części środków stanowiących wartość dodaną w prowadzonej działalności na wzrost wynagrodzeń. Muszą być zatem zachowane stałe, wzajemne relacje bilateralne pomiędzy przedstawicielami załogi, w szczególności realizowane przez związki zawodowe z pracodawcą. Relacje te muszą być oparte na wzajemnym zaufaniu ${ }^{13}$. W tworzeniu wspólnoty zakładu pracy wszelkie kłamstwo, zatajenie, nie może uchodzić za cnotę. Można użyć określenia z języka angielskiego good deal, co będzie oznaczać wzajemne zrozumienie - pracodawca zapewnia pracownikom godziwe warunki pracy i wynagrodzenia, a pracownicy szanują także potrzeby pracodawcy. W procesie tworzenia wspólnoty zakładu pracy wszelkie zakłamanie ze strony pracodawcy podważa wzajemne zaufanie. Tak samo nielojalność ze strony partnerów społecznych, na przykład wkrótce po wprowadzeniu dodatkowych wynagrodzeń związki zawodowe przedkładają nowe żądania, kładzie się cieniem na wzajemne relacje. Można zatem użyć potocznego określenia, że należy zachowywać się fair play. W takich okolicznościach powstaje wzajemna wspólnota, więź wartości i interesów.

Kategoria wspólnoty załogi nie jest dla mnie kategorią, w której uwypuklać należy powszechnie rozumianą jedność. Za brakiem rozumienia wspólnoty załogi nie może przemawiać klasycznie rozumiane przeciwieństwo relacji oraz potrzeb pracowników i pracodawcy. We wspólnocie, jak w każdym organizmie społecznym i tworze socjologicznym, nie ma bezkonfliktowości. Stąd wspólnotę charakteryzuje i wyróżnia nie

${ }^{12} \mathrm{~W}$ tej części opracowania wykorzystałem między innymi myśli, określenia czy poglądy zawarte $\mathrm{w}$ wywiadzie przeprowadzonym z prof. P. Sztompką, Zaburzone zaufanie społeczne, Rzeczpospolita, Plus Minus, 10-11 września $2016 \mathrm{r}$.

${ }^{13} \mathrm{O}$ potrzebie budowy zaufania zob. między innymi J.O. Paliszkiewicz, Zaufanie $w$ zarządzaniu, Warszawa 2013. 
bezkonfliktowość, lecz kwestie wspólne. Wspólnoty jako jednorodności i identyczności poglądów oraz potrzeb w rozumieniu absolutnym nie ma, nie było i nie będzie. Przecież nawet w klasycznym rozumieniu wspólnoty, jaką jest na przykład rodzina, wyraźnie rysują się przeciwne interesy, choćby pomiędzy rodzeństwem. Wspólnotą bez wątpienia jest naród, mimo wielu różnic, choćby w redystrybucji środków z budżetu państwa, $\mathrm{w}$ dostępności do służby zdrowia czy sposobu zaopatrzenia społecznego, a także utrzymywaniu osób notorycznie uchylających się od pracy. Obecny świat zbudowany jest na szeroko rozumianym solidaryzmie społecznym, co od wielu dziesięcioleci eksponuje między innymi społeczna nauka Kościoła katolickiego. Pomimo przeciwstawnych interesów dochodzi także do tworzenia międzynarodowych wspólnot interesów politycznych i gospodarczych (choćby Unia Europejska, która wprawdzie przechodzi kryzys, lecz nikt rozsądny nie formułuje wniosków o jej rozwiązanie). Z tego też względu pojęcia „wspólnota” nie można zawężać wyłącznie do celów, które dla członków wspólnoty muszą być takie same. Takie same, identyczne muszą być jednak podstawowe wartości, a zatem nie wszystkie wartości uznawane przez daną grupę. Takimi wartościami we wspólnocie załogi są godność (poszanowanie drugiego człowieka), prawidłowy rozdział wypracowanych dóbr, pokój społeczny czy lojalność wobec pracodawcy. Istotnego znaczenia nabiera zatem funkcja rozdzielcza (wyrównawcza) prawa pracy, która w przeciwieństwie do eksponowanej na gruncie polskim funkcji ochronnej jest stawiana na pierwszym miejscu w prawie Unii Europejskiej ${ }^{14}$.

Należy zauważyć, że środowisko załogi kreują między innymi lokalni liderzy i posiadany przez nich autorytet, wypracowany przez długi czas. W środowisku, nazwijmy to industrialnym, zachowanie ich nie może być nacechowane przejawem populizmu i doraźnych, często złudnych w perspektywie czasowej, korzyści. Eskalacja żądań wysokich wynagrodzeń może przy dekoniunkturze i braku inwestycji oraz innowacyjności doprowadzić do utraty miejsc pracy. Muszą być zachowane trwałe fundamenty ekonomiczne, będące wartością, której z kolei wspólnota zakładu pracy powinna przestrzegać.

Budowaniu wspólnoty zakładu nie sprzyja globalizacja. Nie żyjemy w próżni. Zauważamy mianowicie, że „za miedzą" ludzie zarabiają lepiej, mają lepszą opiekę socjalną czy lepsze warunki i środowisko pracy. Zjawisko to potęgują środki masowego przekazu, w tym w szczególności nowoczesne środki, między innymi internet, uwypuklając dobrobyt innych. Nie można jednak przechodzić nad tym do porządku i ufać wszystkiemu, co te nośniki informacji nam przekazują. Można to sparafrazować angielskim stwierdzeniem don't believe everything you read on the internet (nie wierz wszystkiemu, co czytasz w internecie) ${ }^{15}$.

Kategoria wspólnoty zakładu pracy w największym stopniu przejawia się w zbiorowym prawie pracy. Zbiorowe prawo pracy bowiem najpełniej realizuje uprawnienia pracownicze. Stwarza mianowicie podstawy prawne, poprzez tworzenie autonomicznych aktów prawa

14 A.M. Świątkowski, Prawo pracy Unii Europejskiej, Warszawa 2015, s. 51 i n.

15 Np. O. Górzyński, Nierówna walka z bzdurą, Rzeczpospolita, Plus Minus, 10-11 września 2016 r. 
pracy (układy zbiorowe pracy, regulaminy wynagradzania czy premiowania oraz inne doraźne porozumienia płacowe), do realizacji indywidualnych potrzeb pracownika, które są podstawą do nawiązania stosunku pracy. Zbiorowe prawo pracy najbardziej dokonuje upodmiotowienia pracowników, poprzez wyrównywanie dysproporcji pomiędzy pracownikami, które miały początek w procesie rekrutacji i których indywidualnie pracownicy nie mogliby zmienić.

Powstaje w tym względzie zasadnicze pytanie: Czy wspólnota załogi zakładu pracy jest wartością i powinna być od strony aksjologicznej objęta ochroną? Czy zatem wspólnota zakładu pracy powinna być objęta stosownymi regulacjami prawnymi, a zatem czy termin „wspólnota zakładu pracy” powinien być wprowadzony do porządku prawnego? A może już de facto i de iure wspólnota załogi istnieje? Uważam, że na tak postawione pytania należy odpowiedzieć twierdząco. Wspólnota zakładu pracy nie jest mianowicie bytem irracjonalnym, lecz faktycznie istniejącym. Współczesny system prawny oparty jest na legalizmie, którego należy bezwzględnie przestrzegać. Oczywiście pomijam tutaj kwestie prawne związane ze stanowieniem tak zwanego prawa niesłusznego ${ }^{16}$, a więc uprawnieniem do oporu („wypowiedzenia posłuszeństwa”). Ma to istotne znaczenie zarówno w indywidualnym, jak i zbiorowym prawie pracy. Pomimo wzajemnych różnic interesów uczestnicy procesu pracy muszą przestrzegać określonych reguł czy wzajemnych powiązań. Muszą przestrzegać pewnych wartości, opisanych w stosownych normach prawnych. Zauważalne jest to choćby w postaci:

A. Pracodawca zobligowany jest do zasięgnięcia opinii lub uzyskania zgody czynnika społecznego, jakim są związki zawodowe funkcjonujące u niego, w przypadku zamiaru rozwiązania umowy o pracę z pracownikiem będącym członkiem związku lub z pracownikiem, który o „ochronę związkową” wystąpił do tej organizacji. Wypowiada się zatem w tym względzie, wprawdzie przez swoich przedstawicieli, załoga zakładu pracy, a więc określona wspólnota. W pewnych sytuacjach ta wspólnota może definitywnie „zablokować” zwolnienie pracownika (na przykład art. $177 \$ 1 \mathrm{kp}$ w przypadku zamiaru rozwiązania umowy o pracę za wypowiedzeniem lub bez wypowiedzenia z kobietą w ciąży lub w okresie urlopu macierzyńskiego).

B. Wspólnota załogi posiada pewne uprawnienia stanowiące. Sprowadzają się do:

- zablokowania obniżenia wynagrodzeń w przypadku przejściowych sytuacji kryzysowych. Mam tutaj na myśli uprawnienia związków zawodowych czy wyłonionych ad hoc ciał przedstawicielskich w celu realizacji norm prawnych zawartych w art. $23^{1 \mathrm{a}} \mathrm{czy} 9^{1} \mathrm{kp}$;

- zawarcia układu zbiorowego pracy. Zawarcie układu uzależnione jest ogólnie ${ }^{17}$ od zgody związków zawodowych. Tak samo jego modyfikacja;

16 Choćby rozważania przeprowadzone przez Gustawa Randbrucha, analizowane przez ze mnie w opracowaniu Prawo pracy - prawo prywatne czy prawo publiczne. Rozważania na tle charakteru umowy o prace, Studia z Zakresu Prawa Pracy i Polityki Społecznej, K.W. Baran (red.), Kraków 2016.

17 Sformułowanie ogólnie odnosi się do faktu, że prawo układowe rozróżnia uprawnienia związków zawodowych posiadających status związków reprezentatywnych i niereprezentatywnych, wśród których 
- zawarcia regulaminu pracy. Identycznie, jak przy układzie zbiorowym pracy, zawarcie tego autonomicznego aktu prawa pracy uzależnione jest ogólnie od zgody związków zawodowych. Tak samo jego modyfikacja.

C. Gromadzenie środków zakładowego funduszu świadczeń socjalnych i następnie ich „rozdysponowanie”. Środki te, pomimo że gromadzone są na oddzielnym koncie pracodawcy, nie stanowią jego własności. Stanowią w świetle prawa dobro, „własność” załogi. Świadczy o tym między innymi fakt, że zgodnie $\mathrm{z}$ art. 3 Ustawy o zakładowym funduszu świadczeń socjalnych ${ }^{18} \mathrm{w}$ przypadku przejęcia pracodawcy lub jego części dokonane w trybie art. $23^{1} \mathrm{kp}$ środki te „idą” wraz z przekazywanymi (przyjmowanymi) pracownikami do nowego pracodawcy.

D. Przedstawicielem załogi zakładu pracy jest społeczny inspektor pracy. W świetle regulacji zawartych w ustawie o społecznej inspekcji pracy ${ }^{19}$ społeczny inspektor pracy jako wyraziciel interesów załogi, a więc wspólnoty, posiada nawet uprawnienia stanowiące sprowadzające się między innymi do de facto wstrzymania ruchu zakładu pracy (art. 11 ust. 2 tejże ustawy).

E. Przejawem defacto bytu prawnego załogi zakładu pracy jest konieczność wyłonienia u niektórych pracodawców przedstawicielstw pracowniczych, jakimi są rady pracowników $w^{20}$. Według stosownych regulacji przedstawiciele załogi posiadają określone uprawnienia w stosunku do zamierzeń, które chciałby podjąć pracodawca, a które odnosiłyby się bezpośrednio do wspólnoty, jaką są pracownicy.

F. Ostatecznie przejawem wspólnoty załogi jest możliwość wszczęcia sporu zbiorowego (oczywiście po spełnieniu określonych wymogów formalnych). W szczególności wyrazem tego jest stanowcza forma referendum załogi jako wspólnoty - bez zgody załogi nie może być przeprowadzony strajk. Decydentem o losach zakładu pracy jest wobec powyższego załoga, która może jako wspólnota przeciwstawić się partykularnym interesom określonych grup w zakładzie pracy czy grze interesów działaczy związkowych. Uwidocznia to tym samym, że na gruncie sporów zbiorowych istnieje wspólnota (oczywiście rozumiana nie jako monolit, lecz większość załogi), którą są łącznie pracownicy i pracodawca. Jest to wspólnota, gdyż jej członkowie mają wspólny cel - zachowanie zakładu pracy i tym samym miejsc pracy.

W przedmiocie sporów zbiorowych osobnej uwagi wymaga okoliczność, iż w procesie rozwiązywania tego konfliktu istotne znaczenie ma zachowanie zasady zachowania pokoju społecznego. Otóż organizatorzy sporu zbiorowego, zgodnie z art. 4 ust. 2 ustawy o rozwiązywaniu sporów zbiorowych ${ }^{21}$ nie mogą wszcząć sporu co do treści

\footnotetext{
uprawnienia tych pierwszych są szersze.

${ }_{18}$ Ustawa z dnia 4 marca 1994 r. o zakładowym funduszu świadczeń socjalnych, tekst jedn. Dz. U. z 2012 r., poz. 592 z późn. zm.

19 Ustawa z dnia 24 czerwca 1983 r. o społecznej inspekcji pracy, Dz. U., Nr 35, poz. 163 z późn. zm.

${ }^{20}$ Ustawa z dnia 7 kwietnia 2007 r. o informowaniu pracowników i przeprowadzaniu z nimi konsultacji, Dz. U., poz. 550 z późn. zm.

${ }^{21}$ Ustawa z dnia 23 maja 1991 r. o rozwiązywaniu sporów zbiorowych, Dz. U. 55, poz. 236 z późn. zm.
} 
układu zbiorowego pracy lub innego porozumienia, którego stroną jest organizacja związkowa w okresie obowiązywania tych aktów prawnych. Przez inne porozumienia, którego stroną jest organizacja związkowa, należy rozumieć wszystkie umowy, ustalenia, ugody itp. zawarte pomiędzy związkami zawodowymi a pracodawcą, w których związki zawodowe występują w imieniu i na rzecz pracowników. Stąd jeżeli przedmiotem sporu zbiorowego byłyby materie już objęte „uprzednio tymi ustaleniami” dokonanymi pomiędzy partnerami społecznymi, to prowadzenie sporu w tym zakresie nie mogłoby nastąpić przed ich wypowiedzeniem. Wyrazem wspólnoty zakładu pracy w przedmiotowej materii jest to, że strony porozumień wyrażają wzajemny szacunek dla uzgodnionych przez siebie norm.

Oczywiście problemem w kategorii wspólnoty załogi jawi się brak w polskim prawie pracy tak zwanej demokracji bezpośredniejej ${ }^{22}$, to jest możliwości podejmowania określonych decyzji przez pracodawcę w wyniku zawarcia szeroko rozumianego porozumienia bezpośrednio z załogą (np. poprzez referendum) z pominięciem organów przedstawicielskich pracowników. Niemniej demokracja, a więc w środowisku pracy głos wspólnoty pracowniczej, realizowana jest przez uprawnione podmioty przedstawicielskie, reprezentujące tę zbiorowość społeczną, którymi z reguły są zakładowe organizacje związkowe.

Kończąc przedmiotowe rozważania, należy wskazać, że pojęcie wspólnoty zakładu pracy ma ogólnie wyraźnie wymiar horyzontalny. Nie można jednak nie zauważać, że zagadnienie to może być rozpatrywane także w wymiarze wertykalnym. Wspólnota zakładu pracy odgrywa bowiem niewątpliwie istotną rolę w zakresie tworzenia więzi lokalnych; wzajemnych powiązań środowiska zakładu pracy z lokalną społecznością w zakresie kultury, sportu czy handlu. Jest to zauważalne na przykładzie takich wspólnot pracowniczych, jak na przykład wspólnota KGHM Polska Miedź SA w Lubinie dla lokalnej społeczności mieszkańców tzw. LGOM. Wspólnota zakładu pracy w wymiarze lokalnym jest dobrem wspólnym.

\section{Zakończenie}

Przeprowadzone rozważania upoważniają do stwierdzenia, że kategoria „wspólnoty zakładu pracy” jest faktycznie i realnie już istniejącym bytem prawnym. Jest nie tylko bytem prawnym, lecz także ekonomicznym czy socjologicznym. Niemniej wyrażam pogląd, że w stosownych regulacjach prawnych powinien pojawić się ten termin, lecz bez jego „ustawowego" definiowania (gdyż normatywne jego zdefiniowanie z uwagi na szerokie spektrum nie jest możliwe), jak np. określenie „staż pracy”. „Definiowanie” powinno być pozostawione doktrynie prawa pracy i w praktyce orzecznictwu sądowemu czy Trybunałowi Konstytucyjnemu.

${ }_{22}$ Zob. na ten temat W. Sanetra, Referendum a prawo pracy, Praca i Zabezpieczenie Społeczne 2015, 10, http://www.pizs.pl/archiwum/praca_i_zabezpieczenie,p1665298936 (dostęp: 30.09.2017). 
Osobnego podkreślenia wymaga również okoliczność, że wspólnota załogi zakładu pracy w aspekcie aksjologicznym oparta jest na płaszczyźnie socjologicznej. Podstawą jej jest środowisko pracy, wzajemne zaufanie członków tej wspólnoty, a tym samym przestrzeganie wzajemnych wartości, także tych zwyczajowych ${ }^{23}$. W sferze ekonomicznej koreluje ze wskaźnikiem dobrobytu, zadowolenia i poziomu życia obywateli państwa. Niewątpliwie kształtuje postawy obywatelskie. Nie sprzyja jej budowaniu autorytaryzm i nepotyzm pracodawcy, a także władcze wkraczanie państwa w każdą sferę relacji pracodawca-pracownicy. Stąd wspólnotę zakładu pracy powinny odzwierciedlać w szczególności regulacje z zakresu prywatnego prawa pracy, opartego na funkcji autonomii w tworzeniu zakładowego prawa pracy ${ }^{24}$.

\section{Bibliografia}

Baran K.W. (red.), Prawo pracy - prawo prywatne czy prawo publiczne. Rozważania na tle charakteru umowy o prace,, Studia z Zakresu Prawa Pracy i Polityki Społecznej, Kraków 2016. Górzyński O., Nierówna walka z bzdura, Rzeczpospolita, Plus Minus, 10-11 września 2016 r. Jaśkiewicz J., Jackowiak C., Piotrowicz W., Prawo pracy w zarysie, Poznań 1980.

Jończyk J., Zakład pracy, w: Zakład pracy. Materiały IV Zimowej Szkoły Prawa Pracy, Karpacz, styczeń 1977, Wrocław 1977.

Kolasiński K., Prawo pracy i ubezpieczeń społecznych, Toruń 1997.

Liszcz T., Prawo pracy, Warszawa 2014.

Paliszkiewicz J.O., Zaufanie w zarządzaniu, Warszawa 2013.

Salwa Z., Szubert W., Święcicki M., Podstawowe problemy prawa pracy, Warszawa 1957.

Sanetra W., Załoga zakładu pracy, w: Zakład pracy. Materiały IV Zimowej Szkoły Prawa Pracy, Karpacz, styczeń 1977, Wrocław 1977.

Sobczyk A., Wolność pracy i władza, Warszawa 2015.

Sztompka P., Zaburzone zaufanie społeczne, Rzeczpospolita, Plus Minus, 10-11 września 2016 r.

Szubert W., O charakterze prawnym stosunku pracy, Państwo i Prawo 1964, 7.

Świątkowski A.M., Prawo pracy Unii Europejskiej, Warszawa 2015.

Świątkowski A., Współczesne brytyjskie zbiorowe prawo pracy, w: Prawo pracy państw obcych, M. Matey (red.), t. III, Wrocław 1989.

Zieliński T., Prawo pracy. Zarys systemu. Część I. Ogólna, Warszawa-Kraków 1986.

Żołyński J., Aksjologiczne, normatywne i społeczne podstawy prawa w rozwiązywaniu sporów zbiorowych pracy, Gdańsk 2016.

${ }^{23}$ Szeroko problematykę zwyczaju w prawie pracy analizuję w monografii Aksjologiczne, normatywne i społeczne podstawy prawa w rozwiązywaniu sporów zbiorowych pracy, Gdańsk 2016, s. 407-410.

${ }^{24}$ Zagadnienie to $\mathrm{w}$ pewnym zakresie analizuję w przywołanej monografii Aksjologiczne, normatywne..., s. 427-432. 